\title{
MIRLET7A3 Gene
}

National Cancer Institute

\section{Source}

National Cancer Institute. MIRLET7A3 Gene. NCI Thesaurus. Code C80701.

This gene is involved in the regulation of gene expression and plays a tumor suppressor role in a broad variety of carcinomas, hematopoietic cancers and other cancers. 